AGRICULTURE AND BIOLOGY JOURNAL OF NORTH AMERICA

ISSN Print: 2151-7517, ISSN Online: 2151-7525, doi:10.5251/abjna.2013.4.1.78.83

(C) 2013, ScienceHuß, http://www.scihub.org/ABJNA

\title{
Effect of feeding varying levels of sheanut meal (Vitellaria paradoxa) on haematological parameters, diseases and mortality of weaner rabbits (Oryctolagus cunniculus).
}

\author{
Alemede, I.C., Ogunbajo, S.A and Akinbiyi, O.J. \\ Department of Animal Production, Federal University of Technology, P.M.B65, Minna - \\ Nigeria. E-mail: tee_baby2k6@yahoo.com
}

\begin{abstract}
This study was conducted to investigate the effect of varying levels of shea nut meal (SNM) on haematological parameter, diseases and mortality of weaner rabbits. Twenty (20) weaner rabbits were used for this study which lasted for 12 weeks. The rabbits were randomly allotted into five treatment groups and replicated, using completely randomized design (CRD). They were fed different diet containing varying levels of shea nut meal (SNM), designated as $\mathrm{T} 1(0 \% \mathrm{SNM})$, T2(10\%SNM), T3(15\%SNM), T4(20\%SNM) and T5(25\% SNM), respectively. Blood samples were obtained from the rabbits and analysed for parameters such as bilirubin level, conjugated bilirubin, alkaline phosphates, serum glutamate oxaloacetate transaminase (SGOT), serum glutamate pyruvic transaminase (SGPT), total protein and albumin. The result showed significant differences $(\mathrm{P}<0.05)$ for all the parameters measured with T4 $(20 \% \mathrm{SNM})$ recording the lowest value for all the parameters except for SGOT which was significantly high. It was concluded that rabbits fed with experimental diet containing up to $20 \%$ SNM showed better performance and did not record any mortality throughout the study period, however up to $25 \%$ level of inclusion may be tolerated without any serious consequencies.
\end{abstract}

Key words: Shea nut meal, haematology, disease, mortality.

\section{INTRODUCTION}

The level of consumption and production of meat in Nigeria is very low (Obioha, 1992 $2^{\mathrm{a}, \mathrm{b}}$ ). Rabbit production like poultry has the potential of improving animal protein consumption by humans in the developing countries including Nigeria (F.A.O. 1990). The rabbitry business is no doubt one of the most attractive fields of agriculture which is witnessing unprecedented acceptance; this is brought about by increasing and persistent demand for rabbits products such as meat, pelt or fur.

Rabbits have a high feed conversion ratio and are efficient converter of plant product and seeds, therefore the expensive nature of convention feedstuff for the formulation of concentrates and pellets has always been a major limiting factor in its production. However, there is the need to urgently incorporate non-conventional feed stuff in rabbit diet for optimum performance and reduction in cost of production to make rabbit consumption viable and solve the problem of scarce and expensive conventional feed stuff.
It has become imperative to turn attention to the exploitation of other legumes, particularly those indigenous to the tropics that are non-conventional, relatively cheap and available when compared with conventional feed stuff like groundnut cake, Soya bean which are the main plant protein source for monogastrics and are very expensive due to competition between man and livestock (Tuleun and Patrick ,2007).

Wild legumes are highly resistant to diseases and pest and exhibit good nutritional qualities (pugilistic et al,. 2004). One of such is the shea nut which is rich in oil and may serve as an energy booster in concentrate ration. A shea tree will bear fruit at between 8 and 15 years. Shea butter is a slightly yellowish or ivory colored natural fat extracted from the seed of the African shea tree by crushing and boiling. It is widely used in cosmetics as a moisturizer. Shea butter is edible and may be used in food preparation or sometime in the chocolate industry as a substitute for cocoa butter.

Shea nut (Vitellaria paradoxa) cake, however, is the by-product of shea butter extraction which is widely distributed in west Africa, the nuts are harvested 
primarily for their fat content, it has good nutrition quality, rich in protein, fat, vitamin, crude fiber and little moisture but very little research has been carried out on the utilization of shea nut. (Ojebiyi et al., 2007) It is also very important to consider the health status of animals used in various feeding trials and one of the ways of assessing it is to evaluate with the use of Haematological studies. Animashaun et al.(2006) observed that nutritional studies should not be limited to performance, carcass quality and nitrogen alone, but the effect on the blood constituent is also very relevant. There is a persistent mortality rate among rabbits annually in different systems of traditional production resulting in severe economic and genetic loses of the viable breeds.

Haematology aid the clinician to arrive at a definitive diagnosis of a disease, enable him/her to make a prognosis and also to assess the efficiency of therapy and toxicity of the drugs and chemical substance (Theodora and Ibeachu, 2005). Haematology and serum biochemistry assay of livestock suggest the physiological disposition of animals to their nutrition. Haematological constituent reflect the physiological response of animal to its internal and external environment which include feed and feeding (Esonu et al., 2001).

This study was designed to:

- $\quad$ determine a safe level to which shea nut meal can be included in rabbit diet.

- $\quad$ evaluate the effect of varying level of shea nut meal inclusion on Haematological profile of weaner rabbits and

- $\quad$ assess the effect of different level of shea nut meal inclusion on diseases and mortality rate of weaner rabbits.

\section{MATERIALS AND METHOD}

The study was carried out at the rabbitry unit of the Ministry of Livestock and Fishery development, Bosso, Minna. Minna is situated on latitude $9^{0} 37^{\circ}$ North and longitude $6^{0} 33^{\prime}$ East. The annual rainfall range between $1,200-1,300 \mathrm{~mm}$ while the annual temperature range is $38-42{ }^{\circ} \mathrm{C}$. Minna is located in the Southern guinea savannah vegetation belt of Nigeria and is characterized by two distinct seasons, the wet season (March-October) and dry season (November-March).

Twenty (20) weaner rabbits aged 4-5 weeks old with a mean body weight of $0.79 \mathrm{~kg}$ were purchased from a good foundation stock in minna. The hutches were disinfected and the environment fumigated before their arrival. The rabbits were raised in hutches which were made of wood, iron and zinc. The hutches were spacious and well ventilated. The hutch has side opening door while the floor is made of wire mesh. The feeders and drinkers were attached to the hutch to avoid water and feed wastage.

The rabbits were randomly allotted into five (5) treatment groups and replicated in a completely randomize design (CRD). They were allowed a pre treatment period of two weeks to enable them acclimatize. Five different diet treatments containing varying level of shea nut (Vitellaria paradoxa) meal were formulated. Treatment 1 (control) had zero level of shea nut (Vitelliria paradoxa) meal. Treatment 2, 3, 4 and 5 had shea nut (Vitellaria paradoxa) meal included at $10 \%, 15 \%, 20 \%$ and $25 \%$ respectively (Table1). Experimental diet and water was supplied ad-libitum. The left over were collected, weighed and recorded daily. Normal management practices were employed during the study period.

Table 1. Composition of experimental diet (\%)

\begin{tabular}{|l|c|c|c|c|c|}
\hline Ingredients & T1 & T2 & T3 & T4 & T5 \\
\hline Maize & 60.54 & 50.99 & 44.65 & 41.42 & 36.66 \\
\hline GNC & 22.21 & 24.76 & 26.11 & 24.33 & 24.04 \\
\hline Rice offal & 10.00 & 10.00 & 10.00 & 10.00 & 10.00 \\
\hline Shea nut meal & 0.00 & 10.00 & 15.00 & 20.00 & 25.00 \\
\hline Salt & 0.50 & 0.50 & 0.50 & 0.50 & 0.50 \\
\hline Bone meal & 3.00 & 0.00 & 3.00 & 3.00 & 3.00 \\
\hline Methionine & 0.25 & 0.25 & 0.25 & 0.25 & 0.25 \\
\hline Lysine & 0.25 & 0.25 & 0.25 & 0.25 & 0.25 \\
\hline Vit/Mix & 0.25 & 100.00 & 100.00 & 100.00 & 0.25 \\
\hline Total & 100.00 & 18.00 & 18.01 & 18.00 & 100.00 \\
\hline Crude protein(\%) & 17.99 & & & 17.99 \\
\hline
\end{tabular}

$\mathrm{T}^{1}=0 \%$ inclusion shea nut (Vitellaria paradoxa) meal

$\mathrm{T}^{2}=10 \%$ inclusion shea nut (Vitellaria paradoxa) meal

$\mathrm{T}^{3}=15 \%$ inclusion shea nut (Vitellaria paradoxa) meal

$\mathrm{T}^{4}=20 \%$ inclusion shea nut (Vitellaria paradoxa) meal

$\mathrm{T}^{5}=25 \%$ inclusion shea nut (Vitellaria paradoxa) meal 
- $\quad$ Composition level of premix supplying $0.25 \mathrm{~kg}$ to the formulated diets.

Vit. A $(8,000,000 \mathrm{IU})$, Vit.$D^{3}(1,500,000,000)$, Vit. $E$ (7,000mg), Vit. K (1,500mg), Vit. $B^{2}(2,500 \mathrm{mg})$, Niacin $(15,000 \mathrm{mg})$, pantothenic acid $(5,500 \mathrm{mg})$, Vit. B6 (2,500mg), Vit. B12 (10mg), Folic acid $(500 \mathrm{mg})$, Biotin $(250 \mathrm{mg})$, Choline chloride (175,000mg), Cobalt (200mg), Copper (3000mg), lodine (1000mg), Iron 921,000mg), Manganese $(40,000 \mathrm{ng})$, Selenium $(31,000 \mathrm{mg})$, Anti-oxidant $(1,250 \mathrm{mg})$.

Signs of diseases were looked out for and record of mortality was taken. Daily post mortem examination was carried out on dead rabbits before disposal. Blood samples were collected in the twelveth week of the experiment from two rabbits per treatment into EDTA treated specimen bottles for heamatological analysis. Blood parameters like, total protein, glucose, serum glutamate oxaloacetate transaminase (SGOT) and serum glutamate pyruvate transaminase (SGPT) were analyzed for.
Data collected were subjected to one way analysis of variance (ANOVA) using Minitab package (MINITAB 2003). Means were separated using Duncan' multiple range test as outline by Steel and Torrie (1980).

\section{RESULTS AND DISCUSSION}

The proximate composition of the experimental diet fed to weaner rabbits indicate that crude protein content varied from $13.25 \%$ in T1 to $19.25 \%$ in T5 and moisture content ranged from $7.65 \%$ in T5 to $8.57 \%$ in $\mathrm{T} 1$, ether extract content ranged from 18.00 $\%$ in $\mathrm{T} 5$ to $24.00 \%$ in $\mathrm{T} 1$. Ash content ranged from $9.03 \%$ in $\mathrm{T} 1$ to $10.30 \%$ in $\mathrm{T} 5$ while crude fibre content ranged from $11.66 \%$ in $\mathrm{T} 1$ to $16.75 \%$ in $\mathrm{T} 5$ (Table 2). An increase was observed in the value of all the parameters measured except ether extract as shea nut meal (SNM) was incorporated into the feed.

Table 2. Proximate composition of the experimental diet fed to rabbits.

\begin{tabular}{|c|c|c|c|c|c|}
\hline & & \multicolumn{2}{|c|}{ Experimented diet } & & \\
\hline Components & $\mathrm{T} 1$ & T 2 & T 3 & T 4 & T 5 \\
\hline Crude protein (\%) & 13.25 & 14.08 & 18.64 & 19.03 & 19.25 \\
\hline Moisture (\%) & 8.57 & 8.98 & 8.98 & 8.66 & 7.65 \\
\hline Ether extract (\%) & 24.00 & 23.00 & 17.00 & 17.90 & 18.00 \\
\hline Ash (\%) & 9.03 & 9.62 & 8.00 & 8.49 & 10.03 \\
\hline Crude fiber (\%) & 11.66 & 10.25 & 19.04 & 18.29 & 16.75 \\
\hline
\end{tabular}

$\mathrm{T}_{1}$ (0\% shea nut meal), $\mathrm{T}_{2}$ (10\% shea nut meal), $\mathrm{T}_{3}\left(15 \%\right.$ shea nut meal), $\mathrm{T}_{4}$ (20\% shea nut meal), and $\mathrm{T}_{5}(25$ $\%$ shea nut meal).

Haematological parameter of weaners rabbit fed varying level of shea nut (Vitellaria paradoxa) meal showed significant $(p<0.05)$ differences among all the experimental animals fed the treatment diet with respect to all the haematological parameters measured (Table 3).

According to Animashaun et al. (2006) and Ojebiyi, et al. (2007), the use of haematological studies is very important in considering the health status of animals used in various feed trials. Olorode et al. (1995) have reiterated that nutrition interferes with the myriads of metabolites and other constituent found in the blood.

In this study, It was observed that the level of total bilirubin, conjugated bilirubin, Alkaline phosphates, SGOT, Total protein and Albumin differed significantly $(p<0.05)$ among the five treatment groups with Diets T2 (10\% SNM) and T3 (15\% SNM) recording higher levels of total bilirubin, conjugated bilirubin, Alkaline phosphates, SGOT and SGPT than the other groups fed $0 \%$ SNM (T1), $20 \%$ SNM (T4) and $25 \%$ SNM(T5). This finding agreed with those of Banerjee (1998) as well as Ekpeyong and Biobaku (1986), who observed similar trend for the aforementioned parameters in a similar study. The authors reported that, under normal circumstance values of SGOT and SGPT in particular are low in the blood, but may become high when the plane of nutrition is low or when there is an occurrence of liver damage which may be further aggravated by the occurrence of diseases like coccidiosis, bloat, diarrhoea, pasteurellosis and a host of others which were all recorded in this study. 
The level recorded for total protein increased as the level of shea nut meal in diet increased. This was a reflection of the proportion of dietary protein level and may portray the health status of the animal. (Babayemi et al., 2003). The level of albumin in the blood was higher in rabbits fed $15 \%$ SNM (T3).
According to Miller et al. (1971), albumin tend to remain constant through out the life of an animal reaching a maximum level at about three weeks of age but may become detrimental to the liver if a decrease/decline occur and vice versa.

Table 3. Haematological parameters of weaners fed varying level of shea nut meal

\begin{tabular}{|c|c|c|c|c|c|c|c|}
\hline Week & T1 & T2 & T3 & T4 & T5 & SEM & LS \\
\hline \multicolumn{8}{|l|}{ Total } \\
\hline Bilirubin level(mmol/L) & $28.38^{b}$ & $44.11^{\mathrm{a}}$ & $43.46^{\mathrm{a}}$ & $27.01^{\mathrm{C}}$ & $32.83^{\mathrm{ab}}$ & 3.31 & * \\
\hline $\begin{array}{l}\text { Conjugated } \quad \text { bilirubin } \\
(\mathrm{mmo1} / \mathrm{L})\end{array}$ & $4.19^{b}$ & $22.05^{\mathrm{a}}$ & $21.74^{\mathrm{a}}$ & $13.50^{\mathrm{C}}$ & $16.41^{\text {ab }}$ & 1.65 & * \\
\hline $\begin{array}{l}\text { Alkaline } \\
\text { Phosphates(i.u/L) }\end{array}$ & $9.43^{\mathrm{ab}}$ & $12.98^{\mathrm{a}}$ & $12.98^{\mathrm{a}}$ & $7.19^{b}$ & $10.73^{\mathrm{ab}}$ & 0.82 & * \\
\hline SGOT (i.u/L) & $4.41^{d}$ & $12.54^{\mathrm{C}}$ & $21.99^{b}$ & $27.40^{\mathrm{a}}$ & $18.72^{\mathrm{cd}}$ & 3.98 & * \\
\hline SGPT (i.u/L) & $19.79^{\mathrm{bc}}$ & $38.00^{a}$ & $8.88^{\text {ab }}$ & $10.60^{c}$ & $30.05^{\mathrm{ab}}$ & 5.17 & * \\
\hline Total Protein $(\mathrm{g} / \mathrm{dl})$ & $5.37^{\mathrm{D}}$ & $6.37^{\mathrm{ab}}$ & $6.15^{\mathrm{ab}}$ & $6.78^{\mathrm{ab}}$ & $7.28^{a}$ & 0.26 & * \\
\hline Albumin(g/dl) & $5.95^{\mathrm{abc}}$ & $6.79^{\mathrm{ab}}$ & $7.14^{\mathrm{a}}$ & $5.30^{c}$ & $5.76^{\mathrm{bc}}$ & 0.24 & * \\
\hline
\end{tabular}

$a, b, c, d$ mean with different subscript on the row are significantly $(p<0.05)$ different

* = significantly difference $(p<0.05)$,

SGOT = Serum glutamate oxaloacetate transaminase

SGPT = serum glutamate pyretic transaminase

SEM = Standard error of means

LS = Level of significant

$\mathrm{SNM}=$ Shear nut meal

$\mathrm{T} 1=0 \% \mathrm{SNM}, \mathrm{T} 2=10 \% \mathrm{SNM}, \mathrm{T} 3=15 \% \mathrm{SNM}, \mathrm{T} 4=20 \% \mathrm{SNM}, \mathrm{T} 5=25 \% \mathrm{SNM}$.

Table 4 reveal some diseases encountered by the weaner rabbits fed with experimental diets. Coccidiosis occurred four times in T5, three times in T1, T2, T4 and two times in T3. Diarrhoea occured twice in T1 and once in T3. Bloat showed up twice in T5 and once in T4. Pastuerellosis shows up once in T2, T4 and T5. Diseases like pneumonia, hemorrhagic enteritis, anaemia and septicemia were detected following post mortem examination of animals. Bloat appeared to be more prominent in the groups that had $20-25 \%$ level of inclusion of shea nut meal in their diet while coccidiosis occurred in all the groups. The spread of these diseases cut across all the group and resulted in death of animal in each of the treatment group except T4 which had $20 \%$ SNM in their diet.

The tables of mortality among weaner rabbit fed with experimental diet indicate that T1, T2, T3 and T5 recorded $25 \%$ mortality while T4 did not record any mortality (0\%) (Table 5). The observation on mortality and spread of disease do not seem to follow any particular pattern and may not be ascribed to the type of feed offered. 
Table 4. Diseases of weaner rabbits fed with experimental diet

\begin{tabular}{|c|c|c|c|c|c|}
\hline Week & T1 & $\begin{array}{c}\text { Treatment diets } \\
\text { T2 }\end{array}$ & T3 & T4 & T5 \\
\hline (n) & 4 & 4 & 4 & 4 & 4 \\
\hline 1 & - & COCCIDISIS & PASTEURELLOSIS & SKIN RASHES & \\
\hline 2 & $\begin{array}{l}\text { DIARRH } \\
\text { OEA }\end{array}$ & - & ANAEMIA & - & COCCIDIOSIS \\
\hline 3 & $\begin{array}{l}\text { COCCI } \\
\text { DIOSIS }\end{array}$ & HERMORAGIC & - & COCCIDIOSIS & BLOAT \\
\hline & & ENTERITIS & & & \\
\hline 4 & - & COCCIDIOSOS & DIARRHOEA & - & SEPTICAEMIA \\
\hline & & & & & $\begin{array}{l}\text { PASTURELLOSI } \\
\text { S }\end{array}$ \\
\hline 5 & - & - & - & PASTEURELLOSIS & COCCIDIOSIS \\
\hline 6 & $\begin{array}{l}\text { COCCI } \\
\text { DIOSIS }\end{array}$ & - & COCCIDIOSIS & - & \\
\hline 7 & $\begin{array}{l}\text { DIARRH } \\
\text { OEA }\end{array}$ & SKIN RASHES & - & COCCIDIOSIS & \\
\hline 8 & $\begin{array}{l}\text { PNEUM } \\
\text { ONIA }\end{array}$ & COCCIDIOSIS & SKIN RASHES & - & BLOAT \\
\hline 9 & - & - & - & BLOAT & COCCIDIOSIS \\
\hline 10 & $\begin{array}{l}\text { COCCI } \\
\text { DIOSIS }\end{array}$ & PASTEURELLOSIS & COCCIDIOSIS & - & - \\
\hline 11 & - & - & - & COCCIDIOSIS & - \\
\hline 12 & - & - & - & - & COCCIDIOSIS \\
\hline
\end{tabular}

Table 5. Mortality among weaner rabbits fed with experimental diet

\begin{tabular}{|c|c|c|c|c|c|}
\hline $\begin{array}{l}\text { Week } \\
\text { (n) }\end{array}$ & $\begin{array}{l}\text { T1 } \\
\text { (4) }\end{array}$ & $\begin{array}{l}\text { T2 } \\
(4)\end{array}$ & $\begin{array}{c}\text { Treatment } \\
\text { T3 } \\
\text { (4) }\end{array}$ & $\begin{array}{l}\text { T4 } \\
(4)\end{array}$ & $\begin{array}{l}\text { T5 } \\
\text { (4) }\end{array}$ \\
\hline 1 & - & - & - & - & - \\
\hline 2 & - & - & 1 & - & - \\
\hline 3 & - & 1 & - & - & - \\
\hline 4 & - & - & - & - & 1 \\
\hline 5 & - & - & - & - & - \\
\hline 6 & - & - & - & - & - \\
\hline 7 & - & - & - & - & - \\
\hline 8 & 1 & - & - & - & - \\
\hline 9 & - & - & - & - & - \\
\hline 10 & - & - & - & - & - \\
\hline 11 & - & - & - & - & - \\
\hline 12 & - & - & - & - & - \\
\hline
\end{tabular}

\section{CONCLUSION AND RECOMMENDATION}

It was observed that the experimental diet had an effect on the performance of the rabbits as indicated by the results obtained. With the exception of blood albumin and total protein, all other haematological parameters evaluated were high in the treatment group, disease condition spread uniformly among the group, however, except for T4 (20\% SNM) which did not record any mortality, other group did. It is therefore recommended that up to $25 \%$ level of SNM may be introduced into the diet of rabbit without any serious negative effect.

\section{REFERENCES}

Aminashaun, R.A., Omoikhoje, S.O and Bamgbose, A.M (2006).Hematological and biochemical indices of weaner rabbit fed concentrate and Syndrella multliflora forage supplement. Proceeding of $11^{\text {th }}$ Annual conference of Animal science Association of Nigeria (ASAN). Ibadan Nigeria. Pp 29-31 
Babayemi, O.J., Bamikole, M.A and Oduguwa, B.O (2001). Hematological and biochemical components of West African dwarf goat fed Teptrosibraclelata based for ate. Tropical Animal production investigation. 6: 31 38.

Banerjee, G.C. (1998). A textbook of Animal husbandry. AVI publisher Inc. USA. $3^{\text {rd }}$ Edition. 134-135

Ekpeyong, T.E and Biobaku, W.O (1986). Growth response of rabbits fed activated sewage and poultry waste. Journal of applied Rabbit Research. 1:14-16

FAO (1990). Food and Agriculture organization: Helianthus, arthropod and protozoa of domesticated annuals. Pp32-40 F.U.T, Student Handbook. 2009/2010 session

Theodora, J.I and Ibeachu, C.O (2005). Time related quantitative change in the value of rat blood kept at room temperature, proceeding of $30^{\text {th }}$ annual conference of the Nigerian Society for Animal Production Nsukka - Nigeria pp41-45.

Miller, Y.H., Benjamin, M.N and schah, O.N (1971). Veterinary chemical pathology, Publisher Inc W.B slanders Ltd. Philadelphia, U.S.A. pp120-112.

MINITAB (2003) Minitab statistical software. Release 14 for windows. State college, Pennsylvania, U.S.A

Obioha, F.C (1992 $\left.{ }^{\mathrm{a}}\right)$. A guide to poultry production in the tropics. Acena publisher, Enugu - Nigeria pp1-10.
Obioha, F.C $\left(1992^{b}\right)$. Alternative source of feed ingredients. Intend paper. Nigeria society for Animal production (NSAP) symposia, NSUKKA.

Ojebiyi, O. O., Farina, G. O., Togun, V. A., Aderinbola, O. A., Olayemi, T. B and Moronfolu, O. O (2007). Study on growth and haematological attribute of weaner rabbit ted graded level of Sun dried Cassava peel, blood meal mixture. Proceeding of the $32^{\text {nd }}$ Annual Conference of the Nigerian Society for Animal Production, 18 - 21th March, 2007. Calabar - Nigeria.

Olorede, B. R., Onifade and Babatunde, G. M (1995) Pugalenthis, M., Vadivel, V., Gurutake - Moorth, P and Janardhanan, K (2004). Comparative Nutrition evaluation of little known legume. Tamarindus indica and Sesbania bispinoja. Tropical and subtropical agro ecosystem. 4:11- 13.

Steel, R. G and Torrie, S. H (1980), Principle and Procedure of Statistics: a biometrical approach. $2^{\text {nd }}$ Edition. London.

Tuluen, C. D and Patrick. J. P (2007) Effect of duration of cooking Mucuna utilis seed on proximate analysis, level of anti-nutritional factor and performance of broiler chicken. Nigerian Journal of Animal Production. 34: $45-53$

Esonu, B. O., Emenalon, O. O., Udedibie, A. B. I., Herbert, U., Ekpor, C.F., Okoli, I.C and Ihekwumere, F. C (2001). Performance and blood chemistry of weaner pig fed raw Mucuna (Velvet bean) meal. Tropical Animal Production Investigation. 4:49 - 54. 